Article

\title{
Vanadium supported on graphitic carbon nitride as a heterogeneous catalyst for the direct oxidation of benzene to phenol
}

\author{
Cheng Wang, Liya Hu, Meiyin Wang, Yuanhang Ren, Bin Yue*, Heyong He\# \\ Department of Chemistry and Shanghai Key Laboratory of Molecular Catalysis and Innovative Materials, Collaborative Innovation Center of Chemistry for \\ Energy Materials, Fudan University, Shanghai 200433, China
}

\section{A R T I C L E I N F O}

\section{Article history:}

Received 17 June 2016

Accepted 21 July 2016

Published 5 November 2016

\section{Keywords:}

Carbon nitride

Vanadium

Benzene hydroxylation

Phenol

Impregnation

\begin{abstract}
A B S T R A C T
A series of graphitic carbon nitride supported vanadium catalysts $\left(x \mathrm{~V} / \mathrm{g}-\mathrm{C}_{3} \mathrm{~N}_{4}\right)$ with different vanadium contents $(x / \%)$ were prepared by impregnation. XRD, FT-IR, TEM, TG-DTG, nitrogen adsorption and XPS characterizations were conducted which revealed a strong interaction between the vanadium species and g- $\mathrm{C}_{3} \mathrm{~N}_{4}$ support. $8 \mathrm{~V} / \mathrm{g}-\mathrm{C}_{3} \mathrm{~N}_{4}$ exhibited the highest activity and showed stable recyclability in the benzene hydroxylation reaction with a benzene conversion of $24.6 \%$ and phenol selectivity of $99.2 \%$ under the optimized conditions. The excellent catalytic performance of $x \mathrm{~V} / \mathrm{g}-\mathrm{C}_{3} \mathrm{~N}_{4}$ was due to the integration of vanadium species with high catalytic activity and the g- $\mathrm{C}_{3} \mathrm{~N}_{4}$ support in their interaction with the benzene substrate.
\end{abstract}

(C) 2016, Dalian Institute of Chemical Physics, Chinese Academy of Sciences. Published by Elsevier B.V. All rights reserved.

reducing agents leads to a limited promise in industrial applications [11]. The difficulties in the large scale production of nitrous oxide also limit its application despite its high performance as an oxidant in the direct benzene oxidation to phenol [12]. In contrast, hydrogen peroxide is a mild and green oxidant with water as the only byproduct, which makes hydrogen peroxide widely used in benzene hydroxylation reaction [13]. Nevertheless, the high activation energy of the benzene $\mathrm{C}-\mathrm{H}$ bonds and the higher reactivity of phenol than that of benzene make the efficient conversion of benzene to phenol challenging. There is a need for the development of efficient and green catalysts for the reaction.

Our previous work indicated that the open $\pi$ system of a graphene oxide support can facilitate the interaction between the support and benzene, which was beneficial to the benzene hydroxylation [14]. As an analogue of graphite, graphitic

\footnotetext{
* Corresponding author. Tel: +86-21-65643916; E-mail: yuebin@fudan.edu.cn

\# Corresponding author. Tel: +86-21-65643916; E-mail: heyonghe@fudan.edu.cn

This work was supported by the National Natural Science Foundation of China $(21371035,21473036)$ and SINOPEC (X514005).

DOI: 10.1016/S1872-2067(16)62496-8 | http://www.sciencedirect.com/science/journal/18722067 | Chin. J. Catal., Vol. 37, No. 11, November2016
} 
carbon nitride $\left(\mathrm{g}-\mathrm{C}_{3} \mathrm{~N}_{4}\right)$ consists of tri-s-triazine rings with $\pi$-conjugated planar layers [15]. Moreover, the rich nitrogen content of g- $\mathrm{C}_{3} \mathrm{~N}_{4}$ affords abundant active sites for chemical modification, which makes g- $\mathrm{C}_{3} \mathrm{~N}_{4}$ widely used as a metal-free catalyst or a promising catalyst support in heterogeneous catalysis [16], including in $\mathrm{CO}_{2}$ activation, water splitting and benzene-involved reactions [17-21]. Based on DFT calculations, Goettmann et al. [22] found that $\mathrm{g}-\mathrm{C}_{3} \mathrm{~N}_{4}$ can activate arenes via electron relocalization due to the $\pi$ orbitals overlapping of the melem units and arenes, especially on the defects of g- $\mathrm{C}_{3} \mathrm{~N}_{4}$, such as edges, curvatures and doping atoms. Chen et al. [23] found that $\mathrm{g}-\mathrm{C}_{3} \mathrm{~N}_{4}$ was able to adsorb and activate benzene chemically, and the phenol yield increased from $1.0 \%$ over $\mathrm{Fe} / \mathrm{SBA}-15$ to nearly $12 \%$ over Fe-g- $\mathrm{C}_{3} \mathrm{~N}_{4} / \mathrm{SBA}-15$ in the oxidation of benzene to phenol using hydrogen peroxide and visible light. Long et al. [24] employed a dual catalyst system $\mathrm{C}_{3} \mathrm{~N}_{4}-\mathrm{H}_{5} \mathrm{PMo}_{10} \mathrm{~V}_{2} \mathrm{O}_{40}$ in the benzene hydroxylation with oxygen as an oxidant and suggested that benzene was activated on the melem unit of $\mathrm{C}_{3} \mathrm{~N}_{4}$. Therefore, the large $\pi$-conjugated system and abundant nitrogen functionalities of g- $\mathrm{C}_{3} \mathrm{~N}_{4}$ may endow g- $\mathrm{C}_{3} \mathrm{~N}_{4}$ with a higher activity than that of graphene oxide as a catalyst support for the direct benzene hydroxylation reaction. Although Ding et al. [25] successfully synthesized V-g- $\mathrm{C}_{3} \mathrm{~N}_{4}$ by the co-synthesis method using urea as a precursor and obtained $18.2 \%$ yield of phenol under optimized conditions, the present catalytic activity remains to be improved and meanwhile, that the structure integrity of $\mathrm{g}-\mathrm{C}_{3} \mathrm{~N}_{4}$ was easily broken and caused partial collapse during calcination resulting from the decomposition of ammonium vanadate needs to be solved [26].

In this work, we report a facile method to prepare a series of $x \mathrm{~V} / \mathrm{g}-\mathrm{C}_{3} \mathrm{~N}_{4}$ catalysts with different vanadium content $(x / \%)$. The catalytic activity of the $x \mathrm{~V} / \mathrm{g}-\mathrm{C}_{3} \mathrm{~N}_{4}$ catalysts was investigated in the benzene hydroxylation reaction using hydrogen peroxide as an oxidant in acetic acid solvent. Systematic characterization were conducted on the $x \mathrm{~V} / \mathrm{g}-\mathrm{C}_{3} \mathrm{~N}_{4}$ catalysts to reveal the relationship between structure and catalytic activity.

\section{Experimental}

Urea and ammonium vanadate $\left(\mathrm{NH}_{4} \mathrm{VO}_{3}\right)$ were purchased and used without further purification from Aladdin Reagent Inc. g- $\mathrm{C}_{3} \mathrm{~N}_{4}$ was prepared based on a reported method with some modifications [27]. Typically, urea was calcined under a nitrogen atmosphere from room temperature to $823 \mathrm{~K}$ with a heating rate of $5 \mathrm{~K} / \mathrm{min}$ and kept at $823 \mathrm{~K}$ for $2 \mathrm{~h}$. After cooling down, the yellow powder was obtained as $\mathrm{g}_{-} \mathrm{C}_{3} \mathrm{~N}_{4}$. To prepare various $x \mathrm{~V} / \mathrm{g}-\mathrm{C}_{3} \mathrm{~N}_{4}$ catalysts, $0.50 \mathrm{~g}$ of $\mathrm{g}-\mathrm{C}_{3} \mathrm{~N}_{4}$ was dispersed in $80 \mathrm{~mL}$ of deionized water. Then $\mathrm{NH}_{4} \mathrm{VO}_{3}(80,112,149$, and 262 $\mathrm{mg}$ ) was added, followed by vigorous stirring for $1 \mathrm{~h}$ at $353 \mathrm{~K}$ and drying at $333 \mathrm{~K}$ overnight. The product was calcined in nitrogen from room temperature to $573 \mathrm{~K}$ with a heating rate of $1.5 \mathrm{~K} / \mathrm{min}$ and kept at $573 \mathrm{~K}$ for $3 \mathrm{~h}$. The sample was labeled as $x \mathrm{~V} / \mathrm{g}-\mathrm{C}_{3} \mathrm{~N}_{4}(x / \%=6,8,10$, and 15) with $x$ standing for the mass fraction (\%) of the initial mass of vanadium to the initial total mass of $\mathrm{g}-\mathrm{C}_{3} \mathrm{~N}_{4}$ and $\mathrm{NH}_{4} \mathrm{VO}_{3}$.
Transmission electron microscope (TEM) images were obtained from a JEOL JEM2011 microscope operated at $200 \mathrm{kV}$. Vanadium mapping images were obtained from an energy dispersive X-ray spectrometer (EDX) combined with a FEI Tecnai $G^{2}$ F20 S-Twin microscope. X-ray powder diffraction (XRD) patterns were recorded on a Bruker D8 Advances X-ray diffractometer using $\mathrm{Cu} K_{\alpha}$ radiation with a voltage of $40 \mathrm{kV}$ and a current of $40 \mathrm{~mA}$. Fourier transform infrared (FT-IR) spectra were recorded on a Nicolet iS10 infrared instrument using $\mathrm{KBr}$ discs. Nitrogen adsorption results were obtained at $77 \mathrm{~K}$ using a Micromeritics Tristar 3000 apparatus. Thermogravimetric (TG) measurements were carried out on a Perkin-Elmer TGA 7 thermal analyzer at a heating rate of $10 \mathrm{~K} / \mathrm{min}$ under a air flow (40 mL/min). X-ray photoelectron spectra (XPS) were recorded on a Perkin-Elmer PHI 5000C ESCA system equipped with a dual X-ray source by using $\operatorname{Mg} K_{\alpha}(1253.6 \mathrm{eV})$ anode and a hemispherical energy analyzer. All binding energies were calibrated with contaminant carbon $(\mathrm{C} 1 \mathrm{~s}=284.6 \mathrm{eV})$ as a reference. The vanadium content of catalysts was measured with a Thermo Elemental IRIS Intrepid inductively coupled plasma atomic emission spectrometer (ICP-AES).

The direct oxidation of benzene to phenol was carried out in a $25 \mathrm{~mL}$ three-necked flask connected with a condenser. Typically, $40 \mathrm{mg}$ of catalyst and $1 \mathrm{~mL}$ of benzene were dispersed in $10 \mathrm{~mL}$ of $80 w t \%$ acetic acid as the solvent. The mixture was heated to $343 \mathrm{~K}$, followed by the dropwise addition of $3.5 \mathrm{~mL}$ of $30 w t \%$ hydrogen peroxide within $30 \mathrm{~min}$ with magnetic stirring. After reacting for another $4 \mathrm{~h}$, the catalyst was separated by centrifugation. The content of liquid products was analyzed by GC9560 gas chromatography (Shanghai Hua-Ai Chromatography Analysis Co., Ltd.) equipped with a flame ionization detector and a HP- 5 capillary column $(0.32 \mathrm{~mm} \times 30 \mathrm{~m} \times 0.25 \mu \mathrm{m}$, Agilent, USA). The products were confirmed by the retention time of the standard samples. The quantitative analysis of the mixture was determined by the calibration curves and using toluene as the internal standard. The conversion of benzene and the selectivity to phenol were calculated as follows: conversion $=n$ (converted benzene) $/ n$ (initial benzene), selectivity $=n$ (phenol) $/ n$ (converted benzene).

\section{Results and discussion}

The XRD patterns of $\mathrm{g}-\mathrm{C}_{3} \mathrm{~N}_{4}$ and $x \mathrm{~V} / \mathrm{g}-\mathrm{C}_{3} \mathrm{~N}_{4}$ catalysts are presented in Fig. 1. All the samples show peaks at $2 \theta$ of $13^{\circ}$ and $27.4^{\circ}$, corresponding to the (100) and (002) diffraction peaks of $g-\mathrm{C}_{3} \mathrm{~N}_{4}$. The peak at $2 \theta=13^{\circ}$ can be attributed to an in-plane structural motif, such as the hole-to-hole distance of tri-s-triazine units, while the peak at $2 \theta=27.4^{\circ}$ was derived from the stacked interlayers of $g-\mathrm{C}_{3} \mathrm{~N}_{4}$ [18]. Although the intensities of the major peaks of $x \mathrm{~V} / \mathrm{g}-\mathrm{C}_{3} \mathrm{~N}_{4}$ catalysts decreased and broadened compared with those of $\mathrm{g}-\mathrm{C}_{3} \mathrm{~N}_{4}$, the basic graphitic structures of $\mathrm{g}-\mathrm{C}_{3} \mathrm{~N}_{4}$ remained after introducing the vanadium species onto the sheets. No characteristic peaks of crystallized vanadium species was observed, implying that the doped vanadium species are small in crystal size or dispersed well on the $\mathrm{g}-\mathrm{C}_{3} \mathrm{~N}_{4}$ layers [26].

The FT-IR spectra of $g-\mathrm{C}_{3} \mathrm{~N}_{4}$ and $x \mathrm{~V} / \mathrm{g}-\mathrm{C}_{3} \mathrm{~N}_{4}$ catalysts are 


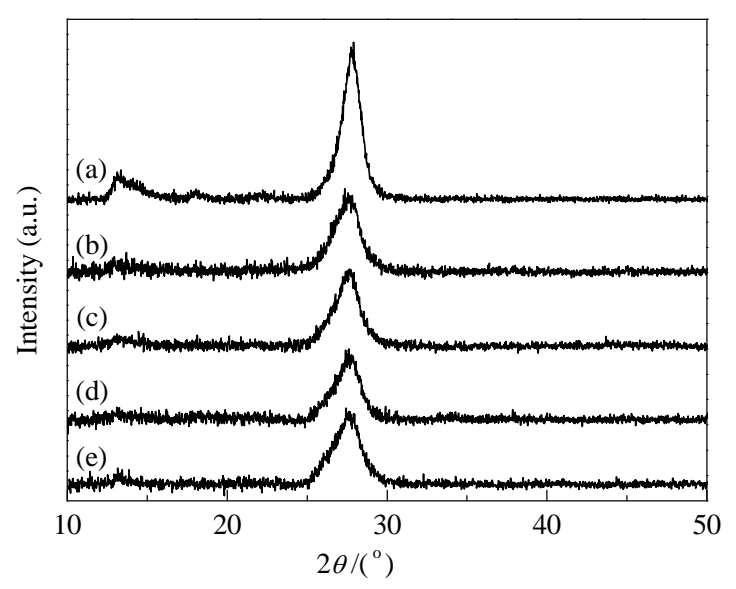

Fig. 1. XRD patterns of (a) g- $\mathrm{C}_{3} \mathrm{~N}_{4}$, (b) $6 \mathrm{~V} / \mathrm{g}-\mathrm{C}_{3} \mathrm{~N}_{4}$, (c) $8 \mathrm{~V} / \mathrm{g}-\mathrm{C}_{3} \mathrm{~N}_{4}$, (d) $10 \mathrm{~V} / \mathrm{g}-\mathrm{C}_{3} \mathrm{~N}_{4}$ and (e) $15 \mathrm{~V} / \mathrm{g}-\mathrm{C}_{3} \mathrm{~N}_{4}$.

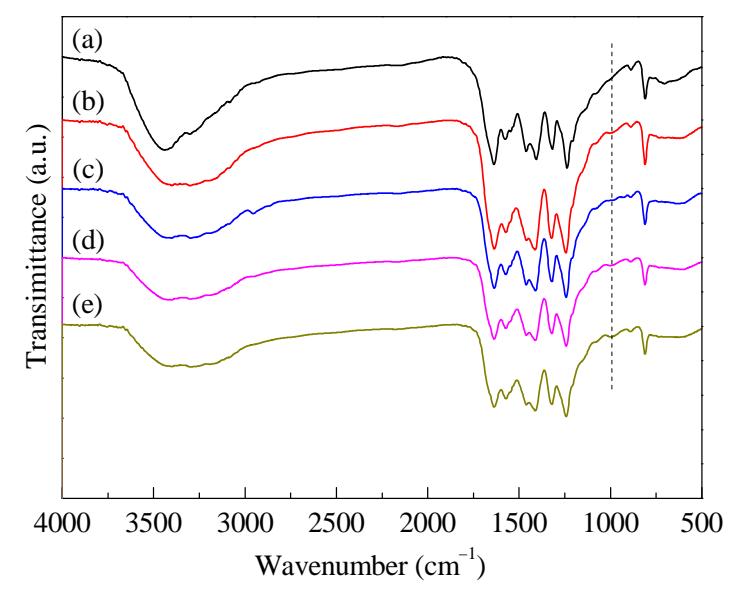

Fig. 2. FT-IR spectra of (a) g- $\mathrm{C}_{3} \mathrm{~N}_{4}$, (b) $6 \mathrm{~V} / \mathrm{g}-\mathrm{C}_{3} \mathrm{~N}_{4}$, (c) $8 \mathrm{~V} / \mathrm{g}-\mathrm{C}_{3} \mathrm{~N}_{4}$, (d) $10 \mathrm{~V} / \mathrm{g}-\mathrm{C}_{3} \mathrm{~N}_{4}$ and (e) $15 \mathrm{~V} / \mathrm{g}-\mathrm{C}_{3} \mathrm{~N}_{4}$.

shown in Fig. 2. All samples manifest similar bands in the region of $1200-1650 \mathrm{~cm}^{-1}$, corresponding to the typical stretching and bending modes of $\mathrm{CN}$ heterocycles. The sharp bands at $810 \mathrm{~cm}^{-1}$ were ascribed to the breathing modes of triazine units $\left(\mathrm{C}_{6} \mathrm{~N}_{7}\right)$, which are the elemental building blocks of g- $\mathrm{C}_{3} \mathrm{~N}_{4}$ structure $[28,29]$. After the incorporation of vanadium species, a broad band appeared in the region of 3000-3500 $\mathrm{cm}^{-1}$ that can be assigned to the stretching vibrations of aromatic $\mathrm{N}-\mathrm{H}$ bonds of uncondensed amino group $\left(-\mathrm{NH}_{2}\right)$, indicating the formation of hydrogen bonds between vanadium species and g- $\mathrm{C}_{3} \mathrm{~N}_{4}[30,31]$. Moreover, a new weak band at 995 $\mathrm{cm}^{-1}$ was also observed after vanadium incorporation. This band was probably caused by the shift of the stretching modes of $\mathrm{V}=\mathrm{O}$ bonds from $1020 \mathrm{~cm}^{-1}$ due to the strong interaction between $\mathrm{VO}_{x}$ species and g- $\mathrm{C}_{3} \mathrm{~N}_{4}[32]$.

The TEM images of g- $\mathrm{C}_{3} \mathrm{~N}_{4}, 8 \mathrm{~V} / \mathrm{g}-\mathrm{C}_{3} \mathrm{~N}_{4}$ and $15 \mathrm{~V} / \mathrm{g}-\mathrm{C}_{3} \mathrm{~N}_{4}$ are shown in Fig. 3. g- $\mathrm{C}_{3} \mathrm{~N}_{4}$ consists of large flat and partially stacked layers (Fig. 3(a)). For 8V/g- $\mathrm{C}_{3} \mathrm{~N}_{4}$ (Fig. 3(b) and 3(c)) and $15 \mathrm{~V} / \mathrm{g}-\mathrm{C}_{3} \mathrm{~N}_{4}$ (Fig. $3(\mathrm{~d})$ ), the vanadium species were dispersed well on the surface of $\mathrm{g}-\mathrm{C}_{3} \mathrm{~N}_{4}$ sheets which was consistent with the XRD results and the $\mathrm{V}$ mapping image of $8 \mathrm{~V} / \mathrm{g}-\mathrm{C}_{3} \mathrm{~N}_{4}$ (Fig. 3(e)). Moreover, the EDX pattern of $8 \mathrm{~V} / \mathrm{g}-\mathrm{C}_{3} \mathrm{~N}_{4}$ further confirmed the existence of vanadium species on the g- $\mathrm{C}_{3} \mathrm{~N}_{4}$ sheets.

The TG analysis was conducted from 298 to $1123 \mathrm{~K}$. As shown in Fig. 4(a), pure g- $\mathrm{C}_{3} \mathrm{~N}_{4}$ has a rapid mass loss from 840 to $1015 \mathrm{~K}$ under a nitrogen atmosphere as a result of complete decomposition. On the DTG curve, the main peak at $984 \mathrm{~K}$ suggested that $\mathrm{g}-\mathrm{C}_{3} \mathrm{~N}_{4}$ was stable during the calcination treatment up to $823 \mathrm{~K}$ in nitrogen. Furthermore, the TG-DTG curves of g- $\mathrm{C}_{3} \mathrm{~N}_{4}$ obtained under an air atmosphere (Fig. 4(b)) showed that g- $\mathrm{C}_{3} \mathrm{~N}_{4}$ was still stable up to $823 \mathrm{~K}$. In contrast, under an air atmosphere, the main exothermic peak at $720 \mathrm{~K}$ of $8 \mathrm{~V} / \mathrm{g}-\mathrm{C}_{3} \mathrm{~N}_{4}$ (Fig. 4(c)) revealed that the existence of vanadium species promoted the oxidization of the $\mathrm{g}-\mathrm{C}_{3} \mathrm{~N}_{4}$ at a relatively low temperature [33]. When the calcination temperature was higher than $790 \mathrm{~K}$, the residue remained constant and can be detected as vanadium pentoxide.

The nitrogen adsorption isotherms are shown in Fig. 4(d). Both samples display the Type IV isotherm with a H1 hysteresis loop along with the distinct capillary condensation step at high relative pressure, indicating the stacked-layer structure of the g- $\mathrm{C}_{3} \mathrm{~N}_{4}$ support [26]. The pure $\mathrm{g}-\mathrm{C}_{3} \mathrm{~N}_{4}$ has a BET surface area of $56 \mathrm{~m}^{2} / \mathrm{g}$, while the BET surface area of $8 \mathrm{~V} / \mathrm{g}-\mathrm{C}_{3} \mathrm{~N}_{4}$ decreased to $49 \mathrm{~m}^{2} / \mathrm{g}$, due to the loading of vanadium species.

The catalytic activity of the catalysts was tested in the direct benzene hydroxylation with hydrogen peroxide as an oxidant. Various reaction conditions (such as catalyst amount, solvent, reaction temperature, reaction time, hydrogen peroxide amount, and the concentration of acetic acid) were investigated to find the optimum one for the present system. As shown in Table 1, the blank experiment in the absence of catalyst revealed no measurable benzene conversion (entry 1). Bare g- $\mathrm{C}_{3} \mathrm{~N}_{4}$ exhibited a trace benzene conversion (entry 2), implying that benzene can be activated by $\mathrm{g}-\mathrm{C}_{3} \mathrm{~N}_{4} . \mathrm{NH}_{4} \mathrm{VO}_{3}$ afforded a benzene conversion of $11.4 \%$ and a phenol selectivity of 88.4 $\%$ (entry 3). Since $\mathrm{NH}_{4} \mathrm{VO}_{3}$ acts as a homogeneous catalyst, the

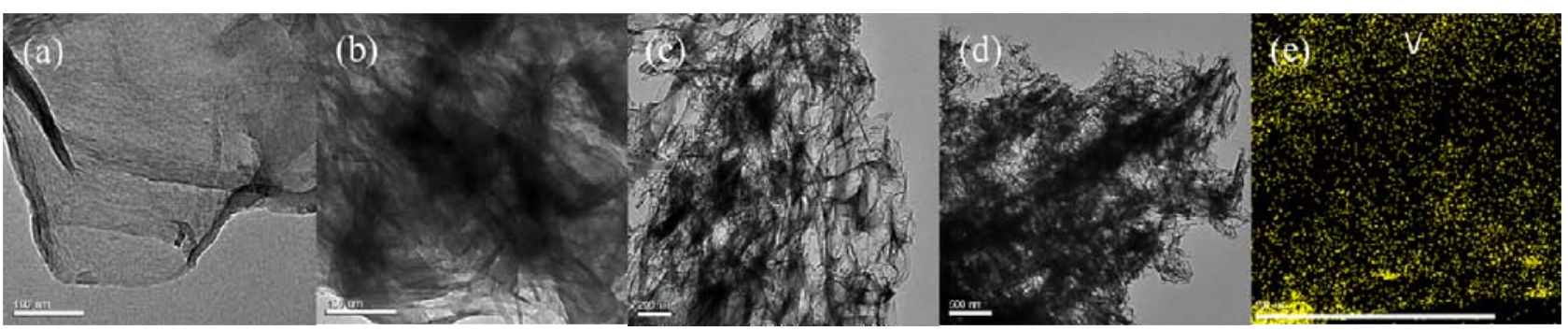

Fig. 3. TEM images of (a) g- $\mathrm{C}_{3} \mathrm{~N}_{4}$, (b, c) 8V/g- $\mathrm{C}_{3} \mathrm{~N}_{4}$, (d) $15 \mathrm{~V} / \mathrm{g}-\mathrm{C}_{3} \mathrm{~N}_{4}$ and EDX measurement of $8 \mathrm{~V} / \mathrm{g}-\mathrm{C}_{3} \mathrm{~N}_{4}$, (e) V mapping. 

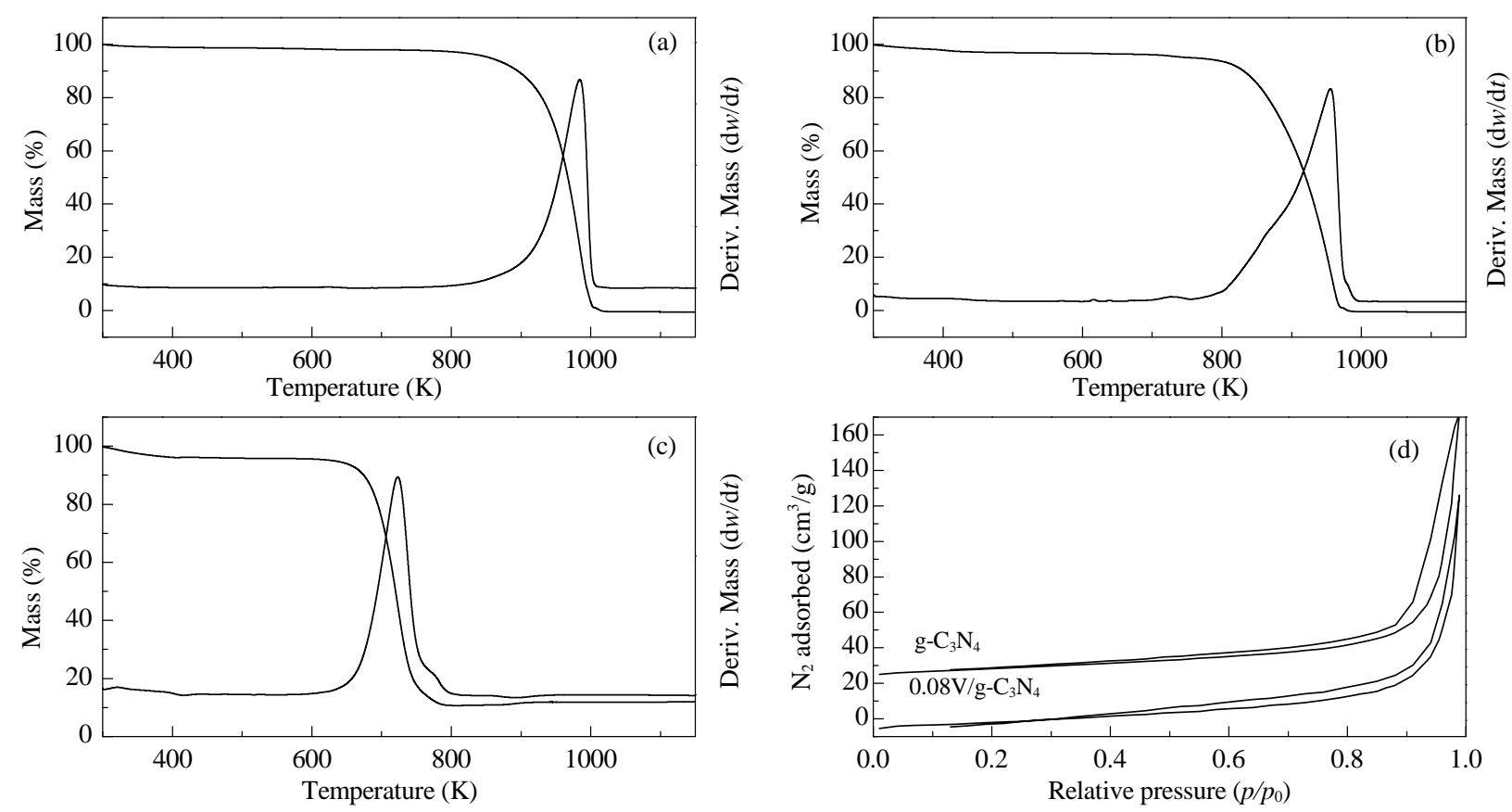

Fig. 4. TG-DTG curves of (a) g- $\mathrm{C}_{3} \mathrm{~N}_{4}$ under nitrogen atmosphere, (b) g- $\mathrm{C}_{3} \mathrm{~N}_{4}$ under air atmosphere, (c) 8V/g-C $\mathrm{N}_{4}$ under air atmosphere and (d) nitrogen adsorption isotherms of $g-\mathrm{C}_{3} \mathrm{~N}_{4}$ and $8 \mathrm{~V} / \mathrm{g}-\mathrm{C}_{3} \mathrm{~N}_{4}$.

consequent rapid $\mathrm{H}_{2} \mathrm{O}_{2}$ decomposition probably led to its limited phenol selectivity. Among the $x \mathrm{~V} / \mathrm{g}-\mathrm{C}_{3} \mathrm{~N}_{4}$ catalysts, $8 \mathrm{~V} / \mathrm{g}-\mathrm{C}_{3} \mathrm{~N}_{4}$ catalyst showed the best performance with a benzene conversion of $24.6 \%$ and a phenol selectivity of $99.2 \%$ (entry 7). Moreover, the TOF values based on the vanadium content further implied that $8 \mathrm{~V} / \mathrm{g}-\mathrm{C}_{3} \mathrm{~N}_{4}$ was the most efficient catalyst in benzene hydroxylation. It is worth noting that the catalytic performance in the present reaction system with a high turnover frequency (TOF $=13.1 \mathrm{~h}^{-1}$ ) was superior to previously reported vanadium doped carbon nitride materials [24-26]. With different reaction conditions, those reported catalysts gave a TOF value in the range of 0.52 to $0.59 \mathrm{~h}^{-1}$ (calculated in the same method mentioned above). The lower activity of $6 \mathrm{~V} / \mathrm{g}-\mathrm{C}_{3} \mathrm{~N}_{4}$ was caused by insufficient active centers for benzene activation (entry 4), while the lower performance of $10 \mathrm{~V} / \mathrm{g}-\mathrm{C}_{3} \mathrm{~N}_{4}$ and $15 \mathrm{~V} / \mathrm{g}-\mathrm{C}_{3} \mathrm{~N}_{4}$ was probably due to the rapid self-decomposition of hydrogen peroxide (entries 5 and 6) accelerated by the large amount of vanadium species.
Furthermore, XPS was employed to investigate the surface vanadium states of $8 \mathrm{~V} / \mathrm{g}-\mathrm{C}_{3} \mathrm{~N}_{4}$, as shown in Fig. 5 . The $\mathrm{V} 2 p_{3 / 2}$ band of the fresh $8 \mathrm{~V} / \mathrm{g}-\mathrm{C}_{3} \mathrm{~N}_{4}$ was deconvoluted into two peaks with the binding energies of 516.9, 517.2 and 515.8, $516.2 \mathrm{eV}$, attributed to $\mathrm{V}^{5+}$ and $\mathrm{V}^{4+}$ species, respectively [34]. The used $8 \mathrm{~V} / \mathrm{g}-\mathrm{C}_{3} \mathrm{~N}_{4}$ after four recycles also consisted of both $\mathrm{V}^{5+}$ and $\mathrm{V}^{4+}$ species, while the relative content of the $\mathrm{V}^{4+}$ species increased after recycling. The existence of $\mathrm{V}^{4+}$ species in $8 \mathrm{~V} / \mathrm{g}-\mathrm{C}_{3} \mathrm{~N}_{4}$ and the $\pi-\pi$ interaction between $\mathrm{g}-\mathrm{C}_{3} \mathrm{~N}_{4}$ and benzene played a role in the excellent catalytic activity of $8 \mathrm{~V} / \mathrm{g}-\mathrm{C}_{3} \mathrm{~N}_{4}[26,35]$.

In order to verify the stability of $8 \mathrm{~V} / \mathrm{g}-\mathrm{C}_{3} \mathrm{~N}_{4}$, the catalyst was separated by centrifugation, dried and re-used. After three more recycle experiments under the optimum conditions (entries 7-9), there was negligible decrease of phenol yield from $24.4 \%$ to $23.3 \%$. After the fourth recycle, the recovered $8 \mathrm{~V} / \mathrm{g}-\mathrm{C}_{3} \mathrm{~N}_{4}$ catalyst was collected and its vanadium content was detected by the ICP-AES. Notably, the structure of $8 \mathrm{~V} / \mathrm{g}-\mathrm{C}_{3} \mathrm{~N}_{4}$ was maintained well and negligible vanadium leaching

Table 1

Catalytic activity of the catalysts for benzene hydroxylation reaction.

\begin{tabular}{|c|c|c|c|c|c|c|}
\hline Entry & Catalyst & Vanadium content (wt.\%) ${ }^{a}$ & Benzene conversion (\%) & Phenol selectivity (\%) & Phenol yield (\%) & TOF ${ }^{b}$ value $\left(\mathrm{h}^{-1}\right)$ \\
\hline 1 & $-\mathrm{c}$ & - & - & - & - & - \\
\hline 2 & $\mathrm{~g}-\mathrm{C}_{3} \mathrm{~N}_{4}$ & - & 0.2 & 65.3 & 0.1 & - \\
\hline 3 & $\mathrm{NH}_{4} \mathrm{VO}_{3}$ & - & 11.4 & 88.4 & 10.1 & - \\
\hline 4 & $6 \mathrm{~V} / \mathrm{g}-\mathrm{C}_{3} \mathrm{~N}_{4}$ & 5.2 & 17.8 & 98.9 & 17.6 & 12.2 \\
\hline 5 & $10 \mathrm{~V} / \mathrm{g}-\mathrm{C}_{3} \mathrm{~N}_{4}$ & 8.9 & 21.0 & 99.3 & 20.8 & 8.4 \\
\hline 6 & $15 \mathrm{~V} / \mathrm{g}-\mathrm{C}_{3} \mathrm{~N}_{4}$ & 14.0 & 17.5 & 97.8 & 17.1 & 4.4 \\
\hline 7 & $8 \mathrm{~V} / \mathrm{g}-\mathrm{C}_{3} \mathrm{~N}_{4}(1$ st run) & 6.7 & 24.6 & 99.2 & 24.4 & 13.1 \\
\hline 8 & $8 \mathrm{~V} / \mathrm{g}-\mathrm{C}_{3} \mathrm{~N}_{4}(2 \mathrm{nd}$ run $)$ & - & 24.1 & 98.9 & 23.9 & - \\
\hline 9 & $8 \mathrm{~V} / \mathrm{g}-\mathrm{C}_{3} \mathrm{~N}_{4}(3 \mathrm{rd}$ run $)$ & - & 24.0 & 98.6 & 23.7 & - \\
\hline 10 & $8 \mathrm{~V} / \mathrm{g}-\mathrm{C}_{3} \mathrm{~N}_{4}(4$ th run $)$ & 6.6 & 23.6 & 98.6 & 23.3 & - \\
\hline
\end{tabular}

Reaction conditions: $40 \mathrm{mg}$ of catalyst, $1 \mathrm{~mL}$ of benzene, $10 \mathrm{~mL}$ of $80 \mathrm{wt} \%$ acetic acid, $3.5 \mathrm{~mL}$ of $30 \mathrm{wt} \% \mathrm{H}_{2} \mathrm{O}_{2}, 343 \mathrm{~K}, 4 \mathrm{~h}$.

a Analyzed by ICP-AES. ${ }^{\mathrm{b}}$ Turnover frequency (TOF) was calculated as molecules of generated phenol per metal atom per hour. ${ }^{\mathrm{c}}$ Blank experiment without catalyst 

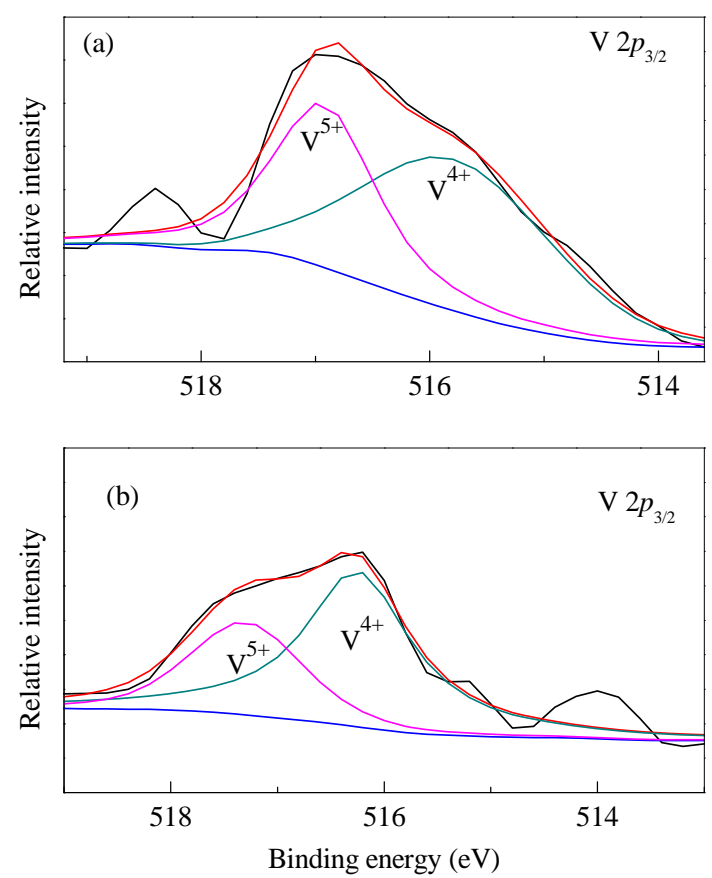

Fig. 5. XPS spectra of (a) $8 \mathrm{~V} / \mathrm{g}-\mathrm{C}_{3} \mathrm{~N}_{4}$ and (b) recovered $8 \mathrm{~V} / \mathrm{g}-\mathrm{C}_{3} \mathrm{~N}_{4}$ after four recycles.

occurred after four recycles, indicating its good stability in the direct oxidation of benzene to phenol. The high catalytic activity and stability of $x \mathrm{~V} / \mathrm{g}-\mathrm{C}_{3} \mathrm{~N}_{4}$ mainly originated from the highly dispersed vanadium species with excellent redox properties and the $\mathrm{g}-\mathrm{C}_{3} \mathrm{~N}_{4}$ support with superior benzene adsorption and activation ability, which provided insight into the future design of efficient catalysts for the reaction.

\section{Conclusions}

A series of $x \mathrm{~V} / \mathrm{g}-\mathrm{C}_{3} \mathrm{~N}_{4}$ catalysts with different vanadium contents were synthesized and evaluated in the direct hydroxylation of benzene to phenol with $\mathrm{H}_{2} \mathrm{O}_{2}$ as the oxidant. Among these catalysts, $8 \mathrm{~V} / \mathrm{g}-\mathrm{C}_{3} \mathrm{~N}_{4}$ showed the best activity with a phenol yield of $24.4 \%$ and selectivity of $99.2 \%$, which were superior to those of previous reported vanadium doped $g-\mathrm{C}_{3} \mathrm{~N}_{4}$ catalysts. Also, $8 \mathrm{~V} / \mathrm{g}-\mathrm{C}_{3} \mathrm{~N}_{4}$ exhibited good reusability during four recycles. Characterization revealed that the vanadium species were highly dispersed over the g- $\mathrm{C}_{3} \mathrm{~N}_{4}$ sheets and the g- $\mathrm{C}_{3} \mathrm{~N}_{4}$ support played a role in the activation of benzene. The efficient combination of high performance vanadium species with an excellent g- $\mathrm{C}_{3} \mathrm{~N}_{4}$ support made the $x \mathrm{~V} / \mathrm{g}-\mathrm{C}_{3} \mathrm{~N}_{4}$ catalysts very promising.

\section{References}

[1] H. Z. Liu, T. Jiang, B. X. Han, S. G. Liang, Y. X. Zhou, Science, 2009, $326,1250-1252$

[2] C. He, J. J. Li, P. Li, J. Cheng, Z. P. Hao, Z. P. Xu, Appl. Catal. B, 2010, 96, 466-475.

[3] P. F. Zhang, Y. T. Gong, H. R. Li, Z. R. Chen, Y. Wang, RSC Adv., 2013, 3, 5121-5126.

[4] R. Kumar, P. Mukherjee, A. Bhaumik, Catal. Today, 1999, 49, 185-191.

[5] K. Nomiya, K. Yagishita, Y. Nemoto, T. A. Kamataki, J. Mol. Catal. A, 1997, 126, 43-53.

[6] Y. Y. Gu, X. H. Zhao, G. R. Zhang, H. M. Ding, Y. K. Shan, Appl. Catal. A, 2007, 328, 150-155.

[7] P. R. Makgwane, S. S. Ray, Appl. Catal. A, 2015, 492, 10-22.

[8] M. Iwamoto, J. Hirata, K. Matsukami, S. Kagawa, J. Phys. Chem., 1983, 87, 903-905.

[9] Y. K. Masumoto, R. Hamada, K. Yokota, S. Nishiyama, S. Tsuruya, J. Mol. Catal. A., 2002, 184, 215-222.

[10] N. K. Renuka, J. Mol. Catal. A, 2010, 316, 126-130.

[11] H. Yamanaka, R. Hamada, H. Nibuta, S. Nishiyama, S. Tsuruya, J. Mol. Catal. A, 2002, 178, 89-95.

[12] R. Leanza, I. Rossetti, I. Mazzola, L. Forni, Appl. Catal. A, 2001, 205, 93-99.

[13] X. F. Zhang, Prog. Chem., 2008, 20, 386-395.

[14] C. Wang, L. Y. Hu, Y. C. Hu, Y. H. Ren, X. Y. Chen, B. Yue, H. Y. He, Catal. Commun., 2015, 68, 1-5.

[15] Y. T. Gong, P. F. Zhang, X. Xu, Y. Li, H. R. Li, Y. Wang, J. Catal., 2013, 297, 272-280.

[16] Y. T. Gong, M. M. Li, H. R. Li, Y. Wang, Green Chem., 2015, 17, 715-736.

[17] F. Goettmann, A. Thomas, M. Antonietti, Angew. Chem. Int. Ed., 2007, 46, 2717-2720.

[18] D. J. Martin, K. P. Qiu, S. A. Shevlin, A. D. Handoko, X. W. Chen, Z. X. Guo, J. W. Tang, Angew. Chem. Int. Ed., 2014, 53, 9240-9245.

[19] L. M. Song, S. J. Zhang, X. Q. Wu, H. F. Tian, Q. W. Wei, Ind. Eng. Chem. Res., 2012, 51, 9510-9514.

[20] X. H. Li, X. C. Wang, M. Antonietti, ACS Catal., 2012, 2, 2082-2086.

[21] J. Xu, Q. Jiang, J. K. Shang, Y. Wang, Y. X. Li, RSC Adv., 2015, 5,

\section{Graphical Abstract}

Chin. J. Catal., 2016, 37: 2003-2008 doi: 10.1016/S1872-2067(16)62496-8

\section{Vanadium supported on graphitic carbon nitride as a} heterogeneous catalyst for the direct oxidation of benzene to phenol

Cheng Wang, Liya Hu, Meiyin Wang, Yuanhang Ren, Bin Yue*, Heyong $\mathrm{He}^{*}$

Fudan University

$x \mathrm{~V} / \mathrm{g}-\mathrm{C}_{3} \mathrm{~N}_{4}$ have been prepared by the impregnation method and $8 \mathrm{~V} / \mathrm{g}-\mathrm{C}_{3} \mathrm{~N}_{4}$ exhibited a superior catalytic performance in the direct benzene hydroxylation.

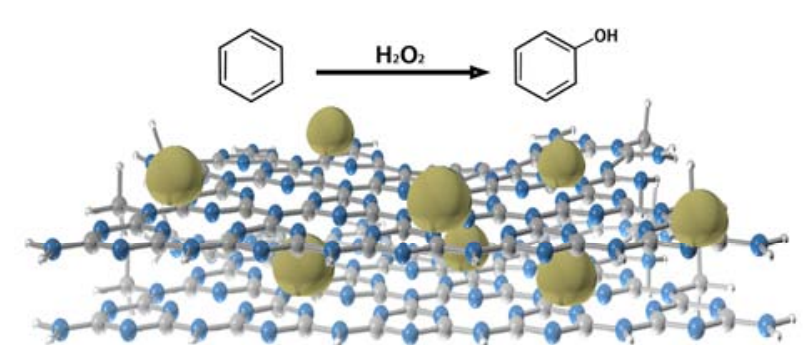


92526-92533.

[22] F. Goettmann, A. Fischer, M. Antonietti, A. Thomas, Angew. Chem. Int. Ed., 2006, 45, 4467-4471.

[23] X. F. Chen, J. S. Zhang, X. Z. Fu, M. Antonietti, X. C. Wang, J. Am. Chem. Soc., 2009, 131, 11658-11659.

[24] Z. Y. Long, Y. Zhou, G. J. Chen, W. L. Ge, J. Wang, Sci. Rep., 2014, 4, 3651-3656.

[25] G. D. Ding, W. T. Wang, T. Jiang, B. X. Han, H. L. Fan, G. Y. Yang, ChemCatChem, 2013, 5, 192-200.

[26] J. Xu, Q. Jiang, T. Chen, F. Wu, Y. X. Li, Catal. Sci. Technol,, 2015, 5, 1504-1513.

[27] F. Dong, L. W. Wu, Y. J. Sun, M. Fu, Z. B. Wu, S. C. Lee, J. Mater. Chem., 2011, 21, 15171-15174.

[28] M. J. Bojdys, J. O. Müller, M. Antonietti, A. Thomas, Chem. Eur. J.,
2008, 14, 8177-8182.

[29] S. C. Yan, Z. S. Li, Z. G. Zou, Langmuir, 2009, 25, 10397-10401.

[30] P. Gibot, F. Schnell, D. Spitzer, Micropor. Mesopor. Mater., 2016, 219, 42-47.

[31] D. Ghosh, G. Periyasamy, S. K. Pati, J.Phys. Chem. C, 2014, 118, 15487-15494.

[32] S. B. Kristensen, A. J. Kunov-Kruse, A. Riisager, S. B. Rasmussen, R. Fehrmann, J. Catal., 2011, 284, 60-67.

[33] T. T. Li, L. H. Zhao, Y. M. He, J. Cai, M. F. Luo, J. J. Lin, Appl. Catal. B, 2013, 129, 255-263.

[34] G. Silversmit, D. Depla, H. Poelman, G. B. Marin, R. De Gryse, J. Electron Spectrosc. Relat. Phenom., 2004, 135, 167-175.

[35] K. Nomiya, Y. Nemoto, T. Hasegawa, S. Matsuoka, J. Mol. Catal. A, 2000, 152, 55-68.

\title{
石墨相氮化碳负载钒作为多相催化剂用于苯直接氧化制苯酚
}

\author{
王 成, 胡丽雅, 王美银, 任远航, 岳 斌, 贺鹤勇 ${ }^{*}$
}

复旦大学化学系, 上海市分子催化和功能材料重点实验室, 能源材料化学协同创新中心, 上海, 200433

摘要: 苯酚是一种重要的化工原料, 目前苯酚的工业生产路线普遍存在工艺流程复杂、苯酚收率低和环境污染严重等问题. 为实现苯酚的绿色生产, 苯直接氧化制苯酚的合成路线受到各国研究者的广泛关注. 在苯直接羟基化反应常用的 $\mathrm{N}_{2} \mathrm{O}, \mathrm{O}_{2}$ 和 $\mathrm{H}_{2} \mathrm{O}_{2}$ 三类氧化剂中, $\mathrm{N}_{2} \mathrm{O}$ 由于来源有限, 其工业应用受到极大限制; 而 $\mathrm{O}_{2}$ 不易活化, 且反应过程中常需还原剂存在, 苯 酚收率低; 相比之下, $\mathrm{H}_{2} \mathrm{O}_{2}$ 作为氧化剂, 其唯一副产物是 $\mathrm{H}_{2} \mathrm{O}$, 而且反应条件温和, 因而以 $\mathrm{H}_{2} \mathrm{O}_{2}$ 为氧化剂的苯羟基化反应 是最具工业应用前景的苯酚合成路线. 然而, 由于苯分子中的 $\mathrm{C}-\mathrm{H}$ 键非常稳定, 活化能较高, 同时产物苯酚的反应活性要 高于反应物苯, 因此, 为实现苯的高效转化, 积极探索研究高活性和稳定性的催化剂变得尤为重要.

在我们之前的研究中发现, 包含大 $\pi$ 体系的氧化石墨烯载体有利于具有同样 $\pi$ 共轭体系的反应物苯的吸附, 进而促进苯 的转化, 提高反应活性. 而石墨相氮化碳 $\left(\mathrm{g}-\mathrm{C}_{3} \mathrm{~N}_{4}\right)$ 具有与氧化石墨烯类似的 $\pi$ 共轭体系, 且表面具有大量的活性位点和缺 陷位, 对苯环类物质具有较好的活化作用, 这使其可能成为更优异的载体材料. 基于此, 以 $\mathrm{g}-\mathrm{C}_{3} \mathrm{~N}_{4}$ 为载体, 采用浸渍法制备 了一系列不同钒含量的催化剂 $x \mathrm{~V} / \mathrm{g}-\mathrm{C}_{3} \mathrm{~N}_{4}$, 并通过 XRD, FT-IR, TEM, TG 等表征技术对催化剂进行了系统研究, 以期揭示 催化剂结构与反应活性之间的构效关系.

$\mathrm{XRD}$ 的表征结果表明, $x \mathrm{~V} / \mathrm{g}-\mathrm{C}_{3} \mathrm{~N}_{4}$ 仍具有载体 $\mathrm{g}-\mathrm{C}_{3} \mathrm{~N}_{4}$ 的层状堆积结构, 且该结构不受钒负载量变化的影响. 同时, $x \mathrm{~V} / \mathrm{g}-\mathrm{C}_{3} \mathrm{~N}_{4}$ 中钒物种的分散度较高, 未发生团聚晶化. 更直观地, 通过 TEM 观察发现, $x \mathrm{~V} / \mathrm{g}-\mathrm{C}_{3} \mathrm{~N}_{4}$ 中的钒物种均匀分散. FT-IR 的表征结果说明钒物种与 g- $\mathrm{C}_{3} \mathrm{~N}_{4}$ 之间存在较强的相互作用. 此外, 通过 TG 表征发现, g- $\mathrm{C}_{3} \mathrm{~N}_{4}$ 高温稳定性较好, 即使 焙烧温度高达 $550^{\circ} \mathrm{C}$, 其结构仍不受影响. 综上所述, 在 $x \mathrm{~V} / \mathrm{g}-\mathrm{C}_{3} \mathrm{~N}_{4}$ 催化剂中, 载体 $\mathrm{g}-\mathrm{C}_{3} \mathrm{~N}_{4}$ 的结构非常稳定, 经负载钒物种 以及焙烧处理后仍能保持不变; 而钒物种与 $\mathrm{g}-\mathrm{C}_{3} \mathrm{~N}_{4}$ 之间存在较强的相互作用, 且均匀分散, 使催化剂具有较高的稳定性和 较好的催化性能.

在以 $\mathrm{H}_{2} \mathrm{O}_{2}$ 为氧化剂, $80 \mathrm{wt} \%$ 醋酸溶液为溶剂的苯直接氧化制苯酚反应中, $x \mathrm{~V} / \mathrm{g}-\mathrm{C}_{3} \mathrm{~N}_{4}$ 催化剂显示了良好的催化活性, 其中反应活性最高的是 $8 \mathrm{~V} / \mathrm{g}-\mathrm{C}_{3} \mathrm{~N}_{4}$ 催化剂, 在最佳反应条件下, 苯酚的收率和选择性分别达到 $24.4 \%$ 和 $99.2 \%$. 同时, 通过 计算 TOF 值发现, 8V/g- $\mathrm{C}_{3} \mathrm{~N}_{4}$ 的 TOF 值高达 $13.1 \mathrm{~h}^{-1}$, 远高于文献中报道的以 $\mathrm{C}_{3} \mathrm{~N}_{4}$ 为载体的催化剂的 TOF 值 (0.52-0.59 $\mathrm{h}^{-1}$ ), 这表明 $x \mathrm{~V} / \mathrm{g}-\mathrm{C}_{3} \mathrm{~N}_{4}$ 催化剂具有优异的催化活性. 此外, 以 $8 \mathrm{~V} / \mathrm{g}-\mathrm{C}_{3} \mathrm{~N}_{4}$ 为代表又进一步考察了催化剂的稳定性, 在回收重 复实验中催化剂的活性保持稳定.

关键词: 氮化碳; 钒; 苯羟基化; 苯酚; 浸渍法

收稿日期: 2016-06-17. 接受日期: 2016-07-21. 出版日期: 2016-11-05.

*通讯联系人. 电话: (021)65643916; 电子信箱: yuebin@fudan.edu.cn

\#通讯联系人. 电话: (021)65643916; 电子信箱: heyonghe@fudan.edu.cn

基金来源：国家自然科学基金 $(21371035,21473036)$ 和中国石化基金 (X514005).

本文的英文电子版由Elsevier出版社在ScienceDirect上出版(http://www.sciencedirect.com/science/journal/18722067). 